\title{
Observations on Intergeneric Transformation between Staphylococci and Streptococci
}

\author{
By W. T. DOBRZAŃSKI, H. OSOWIECKI AND \\ M. A. JAGIELSK I \\ Department of Microbiology and Hygiene, University Medical School, Warsaw
}

(Accepted for publication I April 1968)

\section{SUMMARY}

The occurrence of intergeneric transformation between staphylococci as DNA donors and Streptococcus strain CHALLIS as recipient was controlled. By various methods 126 DNA preparations were isolated from 2 I staphylococcal strains resistant to different antibiotics (I8 produced coagulase and DNase; three were white and did not produce coagulase or DNase). Eight of these preparations, originating from four strains of Staphylococcus aureus were active in intergeneric transformation. The streptomycin-resistance marker was transferred, the yield being $0.00 \mathrm{I}-0.017 \%$ of that of homospecific reaction. The authors did not succeed in transferring the penicillin-, novobiocin-, erythromycin- and oxytetracyclin-resistance markers. Repeated isolations were required to produce active DNA preparations and none of the various methods yielded active preparations consistently. The staphylococcal streptomycin-resistance marker re-isolated from the transformants of strain CHALLIS was transferred to CHALLIS with the same or even higher yield than the homospecific marker.

In the staphylococcal strains from which active preparations were obtained, the GC content was $32 \cdot 7-37 \cdot 6 \%$ and was lower by $4 \cdot 9-9 \%$ from that in strain CHALLIS $(4 \mathrm{I} \cdot 8 \%)$.

\section{INTRODUCTION}

The occurrence of interspecific or intergeneric transformation implies a certain degree of genetic homology between the donor and the recipient strain.

There are a considerable number of publications concerning interspecific transformations in several bacterial genera. They have been described in species of the genera Rhizobium (Balassa, I957), Hemophilus (Leidy, Hahn \& Alexander, 1959), Bacillus (Marmur, Seaman \& Levine, 1963), and in pneumococci and streptococci (Bracco, Krauss, Roe \& MacLeod, I957; Pakula, Hulanicka \& Walczak, I958; Chen \& Ravin, I966).

Intergeneric transformations, on the other hand, have so far been demonstrated only in two cases-namely, between staphylococci and streptococci, and between members of the genera Neisseria and Moraxella (Catlin, 1964). A transformation between staphylococci and streptococci was reported by Pakula et al. (1958). It must be noted that their report was in the nature of a brief mention contained in publication dealing with interspecific transformations in streptococci. Pakula et al. used a transforming DNA isolated from only one staphylococcal strain, ST-70, a standard strain for phage-typing, resistant to streptomycin, novobiocin and erythromycin. As recipients, they employed streptococcal strains-CHALLIS, SANGUIS, MITIS and Strepto- 
coccus pneumoniae sensitive to the three antibiotics mentioned above. Pakula et al. obtained transformants in the streptococcus CHALLIS and SANGUIS strains. The MITIS and Streptococcus pneumoniae strains did not give positive results. They succeeded in transferring only the streptomycin-resistance marker.

These observations were recently questioned by Marmur, Falkow \& Mandel (1963) who wrote that the relation between Staphylococcus and Streptococcus, implied by transformation between these genera, awaited both further experimentation and evidence that the Staphylococcus species employed was properly identified.

In the case of the staphylococci, it has as yet been impossible to obtain homospecific transformations consistently. One of the basic obstacles in effecting repeated transformations in staphylococci may depend on difficulties in obtaining a high-molecular weight, biologically active DNA. This is, most probably, connected with the activity of staphylococcal nucleases. A method for isolating high-molecular weight DNA from staphylococci was described by Blobel (1961). This method is based on procedures for preparing DNA described earlier. However, no report has appeared to date on the biological activity of Blobel's preparations, although Blobel himself suggested such activity.

We undertook our studies on transformation between staphylococci and streptococci to find out, in view of the existing controversies, whether such transformations did in fact occur. We hoped to obtain additional information about the phenomenon, and also wanted to consider the possibility of utilizing such transformations as an auxiliary genetic method in studies on the antibiotic resistance of staphylococci. We decided to perform our studies using numerous staphylococcal strains; we also wanted to test the applicability of various methods of isolating DNA in order to obtain biologically active preparations. In the event of transformation occurring we decided further to examine the base composition of some of the strains used.

\section{METHODS}

Strains. A group $\mathrm{H}$ haemolytic streptococcus strain-CHALLIS-was employed as recipient. In homospecific transformation, a streptomycin-, novobiocin- and erythromycin-resistant mutant of strain CHALLIS served as DNA donor. The two strains originated from the collection of Professor R. Pakula.

For heterologous transformation, DNA was prepared from 2I different staphylococcal strains. These were resistant to $250 \mu \mathrm{g}$. $/ \mathrm{ml}$. dihydrostreptomycin, and some of them were also resistant to penicillin, novobiocin, erythromycin and oxytetracycline. Eighteen of these strains, belonging to different phage types, produced coagulase and exocellular deoxyribonuclease (DNAse). They included strain 70 used by Pakula et al. and Morse's strain S-44 used by Blobel (I96I). Three strains, 480, I3X, I690, produced white pigment and did not produce coagulase or DNAse. All strains came either from the State Institute of Hygiene in Warsaw (Dr J. Jeliaszewicz's Laboratory) or from our own Department.

Transformation reaction. Transformations were performed in a dialysed medium prepared according to Dr R. Pakula (personal communication) $40 \mathrm{~g}$. Neopeptone (Difco) were dissolved in $100 \mathrm{ml}$. distilled water, placed in a dialysing tube (Kalle Aktiengesellschaft-Wiesbaden, Biebrich) and dialysed at $4^{\circ}$ in $\mathrm{I} \cdot 51$. distilled water. In the same manner, $40 \mathrm{~g}$. Difco Yeast Extract were dialysed in $\mathrm{r} \cdot 2 \mathrm{l}$. distilled water. 
After dialysis for $48 \mathrm{hr}$, the diffusates were combined and made up to 2.51 . with distilled water; $0.5 \% \mathrm{NaCl}, 0.17 \% \mathrm{~K}_{2} \mathrm{HPO}_{4}$ and $0.02 \% \mathrm{CaCl}_{2}$ were added; the solution was adjusted to $\mathrm{pH} 8.0$, the medium warmed to $80^{\circ}$ and filtered through filter paper. After the addition of $0.2 \%$ glucose, the medium was adjusted to $\mathrm{pH} 7.6$ and filtered through a Schott G-5 glass filter. This medium was supplemented with $0.2 \%$ of bovine albumin (Sigma). The medium was inoculated with an overnight culture of the streptococcus strain CHALLIS in blood broth to obtained an initial bacterial population density of approximately $4 \times 10^{6}$ viable organisms $/ \mathrm{ml}$. and incubated in a water bath at $37^{\circ}$ until maximum competence (usually 2 to $2.5 \mathrm{hr}$ ) was achieved. Subsequently, $0.2 \mathrm{ml}$. DNA isolated from the different staphylococcal strains was added to a $\mathrm{r} \cdot 8 \mathrm{ml}$. sample of the culture. After $15 \mathrm{~min}$. contact between the bacteria and DNA, the reaction was interrupted by the addition of 20 units DNAse (Distreptaza produced by Biomed, Poland). The cultures were further incubated for I05-II5 min. to allow phenotypic expression of the antibiotic-resistance marker. The samples were then transferred to selective media. The transformants were isolated on blood agar plates containing $250 \mu \mathrm{g} . / \mathrm{ml}$. dihydrostreptomycin (Polfa, Poland), 0.02 or 0.03 units $/ \mathrm{ml}$. penicillin (Polfa), I5 or $25 \mu \mathrm{g} . / \mathrm{ml}$. novobiocin (Lepetit), $0.15 \mathrm{or} 0.25 \mu \mathrm{g} . / \mathrm{ml}$. erythromycin and 4 or $8 \mu \mathrm{g}$. $/ \mathrm{ml}$. oxytetracycline. The erythromycin and oxytetracycline used were standard preparations kindly supplied to us by the Institute of Antibiotics in Warsaw. The yield of transformation was calculated by comparing the number of transformants in $\mathrm{I} \mathrm{ml}$. of the culture with the number of viable bacteria in $\mathrm{I} \mathrm{ml}$. of the culture at the moment the DNA was added. The yield of intergeneric transformation is given as a percentage of that of the homospecific reaction. In preliminary trials, in determining the biological activity of the preparations isolated from staphylococci, the results of transformation were not measured quantitatively. In each experiment the occurrence of spontaneous antibiotic-resistant mutants was thoroughly controlled.

Determination of base composition. The base composition of DNA was estimated according to Marmur \& Doty (1962). The DNA used was prepared as described by Marmur (196I). Tm was determined in a tenfold diluted solution of standard salinecitrate (SSC). In each trial, the Tm of strain CHALLIS DNA was examined simultaneously as a control. To determine the value of $T m$ in SSC, a calculation was made according to Silvestri \& Hill (I965).

\section{RESULTS}

The applicability of various methods of isolating staphylococcal DNA for obtaining preparations active in intergeneric transformation

The study began with an attempt to obtain active DNA preparations from staphylococcus strain 70 used by Pakula et al. (1958). The strain was grown in nutrient broth or in Todd-Hewitt medium. The cocci were incubated at $37^{\circ}$ for $24 \mathrm{hr}$ with strong aeration or in stationary culture. To isolate the DNA, the method, described by Pakula \& Tyc (1956), was used: the coccal sediment was suspended in a tenfold diluted solution of saline-citrate-EDTA (0. I $5 \mathrm{M}-\mathrm{NaCl}+0.015 \mathrm{M}$-sodium citrate $+0.1 \mathrm{M}-\mathrm{Na}$ EDTA) (SWC) and centrifuged. After washing, the cocci were suspended in a $1 / 10$ dilution of SWC and warmed at $65^{\circ}$ for $45 \mathrm{~min}$. The cocci were centrifuged once more and suspended in the enzyme from Streptomyces albus supplemented with $0.015 \mathrm{M}$ sodium citrate. They were incubated with the enzyme in a water bath at $37^{\circ}$ for $12 \mathrm{hr}$. 
From the staphylococcal lysate, the DNA was precipitated with three volumes of ethyl alcohol $\left(96^{\circ}\right)$ and deproteinized by the chloroform method.

Using this method, several DNA preparations from strain 70 were obtained and examined for their ability to transfer streptomycin-resistance to strain CHALLIS;

Table I. Biological activity of staphylococcal DNAs isolated by various methods*

Method of DNA isolation

Pakula \& Tyc (1956)

Catlin \& Cunningham (1958)

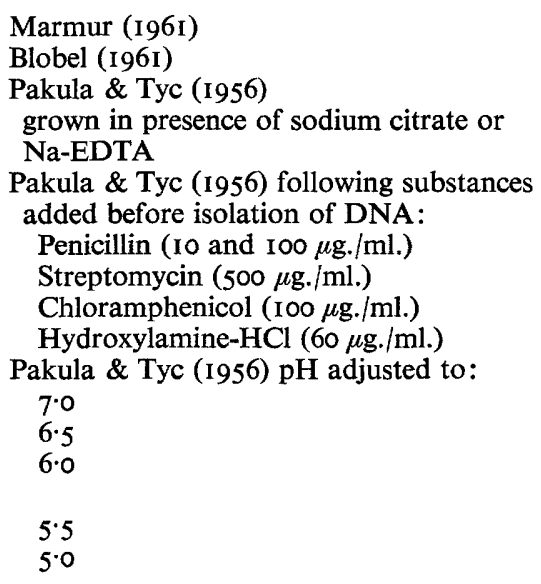

$7,12,13,19,22,25$, 27-SR, 30, 32, 44, 70, 7I, 82, s-44, 27, 64, 209P-SR, 33, I3, 22, 27, 32, 44, 480, I3X, I690

13, 32,

I $3,32, \mathrm{~s}-44$

13

I3, 27-SR
I3, 27-SR


I3, 19, 32
I3, 32, S- 44
$7,13,19,22,32$,
$70,209 \mathrm{P}-\mathrm{SR}$
I3, 32,
I3, 32

Number of preparations

$\overbrace{\text { Total }}^{\begin{array}{c}\text { Active in } \\ \text { transfor- }\end{array}}$
obtained mation

42 $3 \dagger$ 24

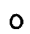

$4 \quad 0$

40

20

* Biological activity was measured in intergeneric transformation using $S$. challis as recipient of the streptomycin resistance markers.

$\dagger$ DNA derived from strains 13,19 and 70.

$\$$ DNA derived from strain 13 .

$\S$ DNA deriving from strain s-44 showed very weak biological activity.

II DNA derived from strains 13 and 32.

II DNA derived from strain 32.

only one was active in heterologous transformation. Consequently, an effort was made to obtain active preparations from other staphylococcal strains by the same method. A total of 42 preparations from 18 different staphylococcal strains producing coagulase and DNAse (including those from strain 70 ) were obtained. Only three preparations isolated from strains 13, I9 and 70, were biologically active (see Table I). Thus, despite careful control of the conditions of the procedure used and repeated isolation of DNA from some of the strains, it was not possible in these tests to get two biologically active preparations from any one strain.

Since difficulty in obtaining a biologically active DNA from staphylococci may be connected with the production of nucleases, attempts were made to modify the 
method of Pakula \& Tyc (1956). The modifications were designed to hinder the production of nucleases or inhibit their activity. In the first of these experiments DNA was isolated from cocci grown in the presence of $14.7 \mathrm{mg} . / \mathrm{ml}$. sodium citrate or $3 \mathrm{mg}$./ml. Na-EDTA. A second series of experiments was carried out in which the cocci, in the final stage of culture, were treated with Io or 100 units $/ \mathrm{ml}$. penicillin, $500 \mu \mathrm{g} . / \mathrm{ml}$. dihydrostreptomycin, $100 \mu \mathrm{g} . / \mathrm{ml}$. chloramphenicol or $6 \mu \mathrm{g}$. $/$ $\mathrm{ml}$. hydroxylamine- $\mathrm{HCl}$. Finally DNA preparations were made at a low $\mathrm{pH}\left(5^{\circ} \mathrm{O}-\right.$ 7.0), making use of the observation by Osowiecki \& Pakula (1962) that, as $\mathrm{pH}$ is lowered, the activity of staphylococcal DNAse decreases.

Furthermore, other methods-those of Catlin \& Cunningham (1958), Marmur (I96I) and Blobel (196I)-were employed in attempts to obtain from staphylococci DNA preparations active in heterologous transformation.

A total of 75 preparations were obtained in these trials from I I different strains of Staphylococcus aureus (see Table I). Only five of them were active. (In addition, one DNA preparation from strain s-44 displayed very weak-and irregular-activity. This was not used in further studies.)

From the three non-pigmented strains which did not produce coagulase or DNAse, nine DNA preparations were isolated by the Catlin \& Cunningham method. None of them was active.

Yield of intergeneric transformation of streptomycin-resistance marker

All the active DNA preparations obtained during these experiments were used to study the transfer of the streptomycin-resistance marker to strain CHALLIS.

The results are presented in Table 2.

Table 2. Yield of intergeneric transformation with the use of DNA from coagulase-positive staphylococci and of streptococcus strain CHALLIS as recipient*

$\begin{array}{lc}\text { DNA donor } & \begin{array}{c}\text { Yield of heterologous } \\ \text { transformation in per- } \\ \text { centage of homo- } \\ \text { specific transforma- } \\ \text { tion }\end{array} \\ \text { Strain CHALLIS } & \text { I00 } \\ \text { Staphylococcus aureus } 13 & 0.017 \\ \text { Preparation no. 1 } & 0.005 \\ \text { Preparation no. } 2 & 0.010 \\ \text { Preparation no. } 3 & 0.003 \\ \text { Preparation no. } 4 & 0.014 \\ \text { S. aureus } 19 & 0.001 \\ \text { S. aureus } 32 & 0.015 \\ \text { Preparation no. I } & 0.002 \\ \text { Preparation no. 2 } & \text { S. aureus 70 }\end{array}$

* The transformation reaction was performed as described in Materials and Methods. The streptomycin-resistance marker was transferred. For methods of obtaining DNA see Table $\mathrm{I}$.

As can be seen from Table 2, the yield of heterologous transformation was low compared with that of homospecific transformation and varied from 0.017 to $0.001 \%$ of that obtained in homospecific transformation, depending on the preparation and on the strain used as donor. 
The yield of heterologous transformation was measured repeatedly at intervals, using the same preparations isolated from strains 13 and I9. The results showed good agreement. The yield of transformation in individual experiments ranged from 0.013 to $0.017 \%$ with the preparation from strain 13 , and from 0.011 to $0.014 \%$ with that from strain 19 .

\section{Time of phenotypic expression of streptomycin-resistance marker}

The time of phenotypic expression of streptomycin resistance was determined as described by Pakula et al. (1962) who examined expression in strain CHALLIS using homospecific transformation.

In our experiments, the staphylococcal streptomycin-resistance marker was expressed phenotypically in the strain CHALLIS recipient $c$. $120 \mathrm{~min}$. from the moment DNA has been added. Thus, the time of expression was identical with that in the case of a homospecific reaction.

\section{Attempts to transfer various staphylooccal antibiotic-resistance markers to Streptococcus strain CHALLIS}

Several attempts were made to transfer resistance to penicillin ( 0.02 and 0.03 units $)$ ml.), novobiocin (I5 and $25 \mu \mathrm{g} . / \mathrm{ml}$.), erythromycin (0.15 and $0.25 \mu \mathrm{g} . / \mathrm{ml}$.) and oxytetracycline ( 4 and $8 \mu \mathrm{g} . / \mathrm{ml}$.) to strain CHALLIS. The DNA preparations used in these experiments were those isolated from Staphylococcus strains 13, 19, 32 and 70 which had proved active in transferring streptomycin-resistance to this recipient.

The results were completely negative.

\section{Integration of staphylococcal streptomycin-resistance marker in strain CHALLIS}

In order to examine the degree of integration of the heterologous streptomycinresistance marker into the genome of strain CHALLIS, three clones were isolated from the transformants obtained in transformations in which DNAs from staphylococcal strains 19 and 70 were used. DNA was isolated from these six transformants and subsequently used for homospecific transformation (Table 3 ).

The results in Table 3 show that the yield of homospecific transformation using DNA re-isolated from the transformants was even higher (20-100\%) that in the case of DNA extracted from a streptomycin-resistant mutant of strain CHALLIS.

\section{Comparison of base composition in DNA of strain CHALLIS and seven staphylococcal strains}

The base composition of DNA in strain CHALLIS and seven staphylococcal strains used in these experiments was examined by $T m$ determination. Four staphylococcal strains which yielded preparations active in heterologous transformation were chosen, as well as three staphylococcal strains from which we did not succeed in obtaining active preparations. The results of these determinations are summarized in Table 4.

There were fairly large differences in the base composition of the various staphylococcal strains; GC content ranged from $31 \cdot 9$ to $37 \cdot 6 \%$. Three strains 64,44 and 30 from which no active preparations were obtained had a somewhat lower GC content than those from which biologically active preparations were obtained. The GC content in staphylococcal DNA preparations active in intergeneric transformations was $4.9-$ $9 \%$ lower than in strain CHALLIS. 
Table 3. Yield of homospecific transformation with the use of DNA re-isolated from strain CHALLIS transformants containing staphylococcal streptomycin-resistance marker*

\begin{tabular}{|c|c|c|c|c|c|c|c|}
\hline & \multirow{3}{*}{$\begin{array}{c}\text { DNA } \\
\text { from } \\
\text { SM-R } \\
\text { mutant } \\
\text { of strain } \\
\text { CHALLIS } \\
\text { (control) } \\
\text { Clone I }\end{array}$} & \multicolumn{6}{|c|}{$\begin{array}{l}\text { DNA re-isolated from strain CHALLIs transformant } \\
\text { containing SM-R marker from }\end{array}$} \\
\hline & & \multicolumn{3}{|c|}{ Staphylococcus aureus 70} & \multicolumn{3}{|c|}{ S. aureus 19} \\
\hline & & Clone I & Clone 2 & Clone 3 & Clone I & Clone 2 & Clone 3 \\
\hline $\begin{array}{l}\text { No. of transformants/ } \\
\mathrm{ml} \text {. }\end{array}$ & $89 \times 10^{4}$ & $130 \times 10^{4}$ & $104 \times 10^{4}$ & $160 \times 10^{4}$ & $150 \times 10^{4}$ & $125 \times 10^{4}$ & $190 \times 10^{4}$ \\
\hline Yield (\%) & $3 \cdot 87$ & $5 \cdot 6$ & $4 \cdot 5$ & $6 \cdot 9$ & $6 \cdot 5$ & $5 \cdot 4$ & $8 \cdot 3$ \\
\hline
\end{tabular}

* DNA was re-isolated from transformants by the Pakula \& Tyc method (1956). Reaction was performed as described in Methods.

Table 4. Comparison of base composition in DNA of seven staphylococcal strains and streptococcus strain CHALLIS*

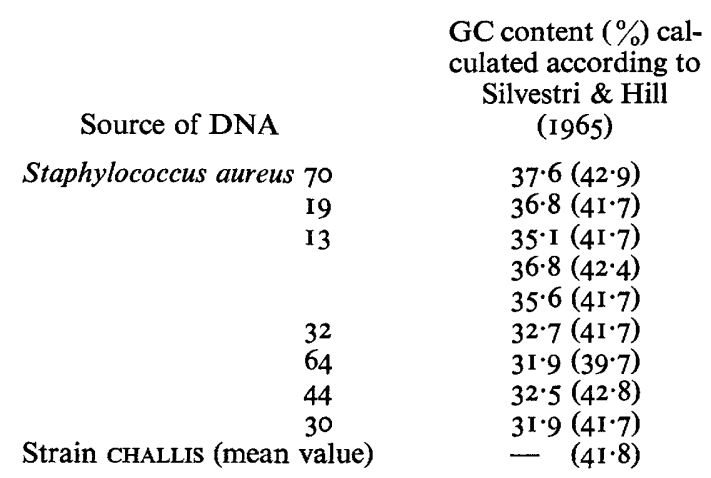

* In each determination of the base content of staphylococcal DNA the GC content of strain CHALLIS DNA was determined as a control. The results of GC determinations of DNA in strain CHALLIS made according to Silvestri \& Hill (I965) are given in parentheses. The result of $4 \mathrm{I} \cdot 8 \%$ for strain CHALLIS is a mean value of nine independent determinations. Biologically active preparations were obtained from staphylococcal strains $70,19,13$ and 32 ; preparations from strains 64,44 and 30 were inactive.

\section{DISCUSSION}

The studies reported above on intergeneric transformation between staphylococci as DNA donors and streptococcus strain CHALLIS as recipient confirm that transfer of the streptomycin-resistance marker does occur. Eight biologically active preparations were obtained from four different strains of Staphylococcus aureus producing coagulase and DNAse. We did not succeed in obtaining active preparations from 14 strains of $S$. aureus and three strains of $S$. albus.

Various methods were used to isolate staphylococcal DNA (Pakula \& Tyc, 1956; Catlin \& Cunningham, 1958; Marmur, I96I; Blobel, 196I). An attempt was also made to obtain active DNA preparations using various modifications of the Pakula \& Tyc method designed, primarily, to inhibit the activity of staphylococcal nucleases. None of the methods yielded regularly staphylococcal DNAs active in intergeneric 
transformation. Active preparations were obtained only by repeated isolations of DNA from some of the strains. Thus, for example, with the use of various methods four out of 50 preparations from strain 13 , two out of 16 preparations from strain 32, and one out of eight preparations from strains 70 and 19 respectively proved to be biologically active.

The yield of transformants in intergeneric transformations was low (0.00I-0.017\%) compared with that obtained in intraspecific transformation (Table 2). It was lower also than the yield of interspecific transformation in Streptococcus (Pakula, I963), Bacillus (Marmur, Seaman \& Levine, 1963) and Hemophilus (Schaeffer, 1958).

However, DNA isolated from transformants of strain CHALLIS into which a staphylococcal streptomycin-resistance marker was introduced gave a high yield of transformants in a homospecific reaction. The yield, in fact, was higher than that obtained in the control reaction (Table 3). This suggests that the staphylococcal streptomycinresistance marker has become fully integrated into the chromosome of the recipient.

In the recipient strain CHALLIS, phenotypic expression of the staphylococcal streptomycin-resistance marker occurred after approx. $120 \mathrm{~min}$; 住us, the period of expression was the same as in the case of the transformation of a homologous marker.

In the experiments described here, only the streptomycin resistance marker was transferred to strain cHALLIS. Despite several attempts, we did not succeed in transferring staphylococcal markers for penicillin, novobiocin, erythromycin and oxytetracycline resistance. As suggested by J. Marmur (private communication) for some species belonging to the genus Bacillus (Dubnau, Smith, Morell \& Marmur, 1965), the streptomycin-resistance marker of Staphylococcus may also perhaps be located on a segment of the chromosome which, in the course of evolution, has retained the base sequence unchanged or almost unchanged, whereas in other chromosomal regions the sequence may have undergone more extensive alterations. If this is so, it may account for the fact that certain markers derived from related species or genera may be capable of integration while others may not.

The considerable difficulties involved in the isolation of active staphylococcal DNA, and also the negative result of the attempts to transfer antibiotic-resistance markers other than the streptomycin-resistance marker, make it impossible for the time being to use intergeneric transformation as an auxiliary method in studying the antibioticresistance of staphylococci.

In the study of base content, use was made of four staphylococcal strains from which biologically active preparations were isolated, and of three strains from which it was not possible to obtain such preparations. The GC content in strain CHALLIS was examined as well. In agreement with the reports in the literature (Hill, I966), the differences in GC content in staphylococci proved to be quite considerable ( $31^{\circ} 9-$ $37.6 \%$ ). The three staphylococcal strains from which no active preparations were obtained had a somewhat lower GC content than those from which such preparations were secured. However, this fact may be accidental and it is impossible to comment on it within the terms of reference of the present study. On the basis of several determinations it was found that the mean GC value in strain CHALLIS was $4 \mathrm{I} \cdot 8 \%$. Bankowska (I963) reported that GC in strain CHALLIS amounted to $4 \mathrm{I} \%$, and Chen \& Ravin (1966) determined the GC content in this strain to be $36.4 \%$. However, the latter authors performed their determination using the bromination method.

The differences in GC content in the DNA of strain CHALLIS and the staphylococcal 
strains from which active preparations were obtained proved to be considerable and varied between 4.8 and $9 \%$. The present study demonstrates the possibility of the occurrence of heterologous transformation (although of one marker only) in spite of rather large differences in the respective base content of the strains used in the reaction. In view of this, it seems advisable to elaborate with greater precision the opinion encountered in the literature (Marmur, Falkow \& Mandel, 1963; Pakula, 1963) that similarity in base content between donor and recipient is an indispensable, though not the only, requirement for the occurrence of heterologous transformation in bacteria.

The authors are indebted to Miss Barbara Glinicka and Miss Alina Stępczyńska for their valuable technical assistance.

\section{REFERENCES}

BALASSA, R. (1957). Durch Desoxyribonukleinsäuren induzierte Veränderungen bei Rhizobien. Acta microbiol. hung. 4, 77.

Bańkowska, Z. E. (1963). Doctoral Thesis, Polska Akademia Nauk, Instytut Biochemii i Biofizyki, Warszawa.

BLOBEL, H. (196I). Isolation and characterization of deoxyribonucleic acid from a strain of Staphylococcus aureus. J. Bact. 82, 425 .

Bracco, R. M., Krauss, M. R., Roe, A. S. \& MacLeod, C. M. (1957). Transformation reactions between pneumococcus and three strains of streptococci. J. exp. Med. 106, 247.

CATLin, B. W. (1964). Reciprocal genetic transformation between Neisseria catharralis and Moraxella nonliquefaciens. J. gen. Microbiol. 37, 369.

Catlin, B. W. \& Cunningham, L. S. (1958). Studies of extracellular and intracellular bacterial deoxyribonucleic acids. J. gen. microbiol. 19, 522.

Chen, K. C. \& RAvin, A. W. (I966). Heterospecific transformation of pneumococcus and streptococcus. J. molec. Biol. 22, I09.

Dubnau, D., Smith, I., Moreli, P. \& Marmur, J. (1965). Gene conservation in Bacillus species, I. Conserved genetic and nucleic acid base sequence homologies. Proc. natn. Acad. Sci., U.S.A. 54, 49 I.

HILL, L. R. (1966). An index to deoxyribonucleic acid base compositions of bacterial species. J. gen. Microbiol. 44, 419.

Leidy, G., HaHN, E. \& AleXander, H. E. (1959). Interspecific transformation in Hemophilus: a possible index of relationship between $H$. influenza and H. aegyptius. Proc. Soc. exp. Med. Biol. I02, 86.

MARMUR, J. (1961). A procedure for the isolation of deoxyribonucleic acid from micro-organisms. J. molec. Biol. 3, 208.

MARMUR, J. \& DotY, P. (1962). Determination of the base composition of deoxyribonucleic acid from its thermal denaturation temperature. J. molec. Biol. 5, rog.

Marmur, J., Falkow, S. \& Mandel, M. (1963). New approaches to bacterial taxonomy. A. Rev. Microbiol. 17, 329.

Marmur, J., Seaman, E. \& Levine, J. (1963). Interspecific transformation in Bacillus. J. Bact. 85, $46 \mathrm{I}$.

Osowiecki, H. \& Pakula, R. (I962). Badania nad dezoksyrybonuleazy gronkowcową I. Pomiar aktywności dezoksyrybonukleazy gronkowcowej metodą wiskozymetryczną. Medycyna dośw. Mikrobiol. 14, 173.

PaKUla, R. (1963). Can transformation be used as a criterion in taxonomy of bacteria? Recent Progress in Microbiol. VIII, p. 617. University of Toronto Press.

PakUla, R., Hulanicka, E. \& WALCZAK, W. (I958). Transformation reactions between streptococci, pneumococci and staphylococci. Bull. Acad. pol. Sci. Cl. II. Sér. Sci. biol. 6, 325.

Pakula, R., Piechowska, M., Bańkowska, E. \& Walczak, W. (I962). A characteristic of DNA mediated transformation systems of two streptococcal strains. Acta microbiol. polon. rI, 205. 
Pakula, R. \& Tyc, M. (1956). Zastosowanie czynnika litycznego ze szczepów z rodzaju Streptomyces (aktynomycetyny) do ekstrakcji kwasu dezoksyrybonukleinowego z bakterii. Medycyna dośw. Mikrobiol. 8, 523 .

SchaefFer, P. (1958). Interspecific reactions in bacterial transformation. Symp. Soc. exp. Biol. 12, 60.

Silvestri, L. G. \& Hill, L. R. (1965). Agreement between deoxyribonucleic acid base composition and taxometric classification of Gram-positive cocci. J. Bact. 90, I36. 